Former Trading Centres of the Persian Gulf. V. Kung Author(s): A. W. Stiffe

Source: The Geographical Journal, Vol. 13, No. 3 (Mar., 1899), pp. 294-297

Published by: geographicalj

Stable URL: http://www.jstor.org/stable/1774668

Accessed: 27-06-2016 07:50 UTC

Your use of the JSTOR archive indicates your acceptance of the Terms \& Conditions of Use, available at

http://about.jstor.org/terms

JSTOR is a not-for-profit service that helps scholars, researchers, and students discover, use, and build upon a wide range of content in a trusted digital archive. We use information technology and tools to increase productivity and facilitate new forms of scholarship. For more information about JSTOR, please contact support@jstor.org.

The Royal Geographical Society (with the Institute of British Geographers), Wiley are collaborating with JSTOR to digitize, preserve and extend access to The Geographical Journal 
to verify his statements. I do not pretend that my channels are all absolutely perfect, that they are not incapable of being modified and improved, but I have drawn them to the best of my ability. I think the best way for any person who doubts them is to get the Admiralty Charts, to adopt the plan that I have adopted, and draw the isobathic lines for himself, and then he will have better ground for disputing them. Dr. Gregory's views of improbability have no weight with me at all. Questions of probability or otherwise in natural science subjects are matters. which I cannot possibly recognize. As for the Congo and the cañon of deposition, I think that is a very questionable argument indeed. I understand this sub-oceanic channel of the Congo is of enormous depth, and it is quite impossible to admit that it could have been formed by the heaping up of materials on each side. Why should the materials be heaped up on each side? Once a river goes into the ocean, the current very soon ceases, and the waters become subject to the currents which move around it, the tendency of which is to spread the materials-and to fill up hollows rather than allow of their being piled up on each side, as described by Dr. Gregory. I think, sir, that is all that is necessary for me to say in reply.

The President : I think the chief point on which Prof: Hull finds disagreement with those who have joined in the discussion, is with regard to the question of geological time, which is not a geographical question at all: But most of the gentlemen who have discussed the paper were agreed that Prof. Hull's method of ascertaining the contours and the shape of the ocean bed by means of the examination of soundings, is a correct one, and any of the points in which he is mistaken were probably consequent on the want of materials. No doubt, if he continues his investigations in some points he will be confirmed, and in others perhaps he will not be confirmed, in his present views. He has merely formed his opinions on the actual material that was before him, on the charts, and he has certainly given us a most interesting paper. I am sure you will all join in a very cordial vote of thanks to Prof. Hull and to those who have joined in the very interesting and important discussion which followed.

\title{
FORMER TRADING CENTRES OF THE PERSIAN GULF.
}

\author{
By Captain A. W. STIFFE, R.I.M.
}

\section{KUNG.}

THIS is now only a large fishing village, chiefly of mat huts, extending about half a mile along the low sandy shore, and containing perhaps 2000 inhabitants. It stands on the Persian coast about $3 \frac{1}{2}$ miles north-eastward of Linga. There is a large date grove and much cultivation at the back of the place. The fishermen, as usual on this coast, are of Arab descent, the cultivators Persian. There is a fair anchorage, sheltered from the prevailing winds, but open to the "saheili," or south-wester, which is of rare occurrence, but occasionally blows with considerable force. The beach is shelving, and landing for boats bad in consequence, except at high water. There are extensive mounds and ruins of the old town of two to three hundred years ago, and remains of large hummums. The walls of the old Portuguese factory, a large white ruined building, still stood at the time of our visit, but in a very tottering condition. It was a commodious square building of several stories. Opposite to it stands a round fort of good masonry, which is surrounded by the sea at high water; it is circular in form, not above 20 yards across, and has several embrasures for guns, and some vaulted casemates or chambers underneath. There is a large excavation near the factory, which, we were 
informed by the people, had been a dock-a sort of mud dock, I presume. There is little produced here, except a common kind of pottery, there being good pottery clay near.* At one time, it was told us, very superior pottery was made here.

The land slopes gently up from the shore to a height of several hundred feet, and presents, as in so many places in these parts, a geologically recent calcareous crust, largely composed of shelly débris, overlying thick beds of clay, which formation leads to very broken ground being formed by the washing away of the clay. This sloping ground ends abruptly in little cliffs a few miles inland, beyond which is an extensive plain of clay, barren, and level. At the back of the rising ground, 5 or 6 miles to north-westward of the place, rises a detached hill, an outlier of the same formation, to a height of 600 feet. It has precipitous sides. There is a narrow difficult path up to the top, which is covered with ruins, and many watercisterns to catch rain-water-more than a hundred, we are told-of the usual description; they are oblong excavations in the ground, cemented inside, and have arched roofs to prevent evaporation, which have mostly fallen in, and choked the cisterns. They are common all along the coast at the present day. The ruins were mere mounds, and no inscriptions could be found. The path up has been fortified, and walls built along the edge of the cliffs where at all practicable. Nothing seems to be known of its origin. It is now called Kaleh-Lestán.

\section{HISTORY.}

Kung is not a place of great antiquity, and it appears to have risen to importance only after the expulsion of the Portuguese from Hormúz, when they established a settlement here, and it appears to have become their headquarters, and a place of some trade.

In 1652, Tavernier $\dagger$ went from Basra to Congo (Kung), where, he says, there is a "Portugais" factor, who receives half the customs; he also mentions that the road from Lar (the capital of the province) to Congo is bad by reason of want of water and craggy, narrow ways.

Between 1693 and 1699, $\ddagger$ Dr. Gemelli Carreri travelled from Shiráz to Lar and Congo; he also complains of the horrible roads, passed over the "rude montagne" of Chiampa, which has on the summit the "Karvansera de Serkou" (Sár-i-kuh, i.e. summit of mountain), two miles from which they sighted the Persian gulf and Bander Congo descent, environed by precipices into the plain, where were several small hills of different colours. At Congo, Joseph Pereira d'Azevedo was superintendent of the royal Portuguese agency; they lodged at the convent of the Augustins. The Portuguese received an annual tribute of five horses and 1100 . tománs (about $\mathbf{f 5}^{\mathrm{j} 00}$ ), by a convention made after the Persians had taken Ormus, because the Portuguese troubled with their vessels the navigation of the whole gulf, which lessened the customs (of Persia); and, besides, they had the great

* We were told a curious story about this pottery, which is not incredible in that country. The artisan who improved the manufacture was doing well for himself and getting known, when an order came down from Teheran to the local governor, that he was to be sent up to the capital, where he was appointed to be maker of china to the Shah. The man feared that if he went to Teheran he would have to make pottery for every one connected with the court, and never receive any pay, so he took all the money he had made to the governor, and implored him to report that the man who made the good pottery was gone, no one knew where. After which he never made any more good pottery.

† 'Collection of Travels of Tavernier', etc. London, 1684.

‡ 'Voyage autour du monde,' Traduit de l'Italien de Gemelli Carreri. Paris, 1727. 
privilege of having a house, hoisting their flag, and jurisdiction over all Christians landing. At first they received half the customs, but, owing to disputes, it was compounded for the above annual payment. The narrative says the superintendent gives passes to Mohammedans for safe navigation of the Indian seas, and sells the prizes taken by Portuguese vessels. Bander Congo, which is open to the sea, is in lat. $27^{\circ}$ (really $26^{\circ} 35^{\prime}$ ). "Nearly all the houses are of mud; only some near the sea are of stone. It is a dependence of Lar, under a deroga and chabander (shahbandar, customs officer). It is a country of great trade, vessels continually arriving from India, Basra, Arabia Felix, and other places, besides caravans without number. The chief trade is in pearls, fished up in the isle of Baharen and all the gulf; they are bought cheap, wholesale from the fishers," and sold dear in retail." He then describes the little copper sieves, still used, for sorting the different sizes, and the separation of the round and white from the misshapen and stained or of less clear water; also the skilful boring by the Arabs, "so that one can scarcely see the hole;" also he refers to the method of bargaining with the hands under a cloth, which is still practised. He mentions the unhealthiness and great beat, "so that even the birds hide themselves in the trees;" the people go nearly naked, the rich clothed with "very fine stuff." He mentions the wind-towers on the houses, and says Bander Abassi is still hotter; and also describes the guinea-worm absolutely exactly, with the practice of winding it slowly out of the flesh. "The roadstead is defended by a fort, 30 'palms' square, and armed with four iron cannon, made by order of D. Constantine de Norogna" + (Noronha?) when he was viceroy for the King of Spain. Water was only obtainable from cisterns, as at the present day, on this coast.

He saw vessels of the Portuguese, of sixty and seventy guns, lying off Congo, and says, "I know only the English and Dutch go to Gomroon (Bandar Abbas); all other nations trafic at Congo, on account of the security given by the power and maritime force of the Portuguese. There are about 10,000 inhabitants-Moors, Indians, Arabs, Jews, and Armenians, who have fine shops." He gives a good description of the pearl fishery, and the submarine springs at Bahrein.

He also describes the "ship"-building, and says, "Instead of nails, which they are without, they use 'chevilles' (pegs) of bamboo or cane, and further join the planks with 'ficelles' (strings) made of rushes (probably coir or coconut fibre). For anchor, they have a large stone with a hole, and for oars, a stout stick with a little round plank attached to the end." All this is unchanged at the present day for the coasting boats. He attended mass and visited the bazar, being astonished at the men "who put burning coal in their mouths like cherries, by the aid of the demon," sn he was told. During the Diváli (the great Hindu holiday), the "Banianes" (the Hindu merchants) had a "Nautch," which he describes at length, and "which pleased him so much that he wanted to. see them again and again." He also visited Kalah Lestán (see ante). He sailed for India in a " Moorish" ship, as the Portuguese were at war with the Maskat Arabs, and had a long passage, being driven back from Pasni (on the Makrán coast) to near Jashk, " owing to the incredible ignorance of the pilot, who was sailing by chance, never having had any other business than tobacco-seller." The captain had recourse to our traveller, who seems to have taken charge, and "on the 16 th we found

* This is now chiefly done at Linga, a large town, the successor of Kung, nearly 4 miles to the south-westward.

$\dagger$ From Danvers' book, 'The Portuguese in India,' it appears Constantin de Noronha was Captain-General of Ceylon in 1629. Don Miguel de Noronha was viceroy 1629 to 1635 . 
ourselves at the same place as eleven days before-delay to which those are exposed who embark in Moorish vessels" (he philosophically remarks).

As to the date of the occupation of Kung, the Chevalier Chardin, * between 1671 and 1677, visited "Congue." He says that in 1625 the Portuguese surrendered Bahrein to Persia, and other small islands, "on contract to get half the customs of Congue." He says they got tribute from even the smallest boats, and permitted no trade with India except in their own ships. After the fall of Hormuz (1622), the Portuguese retired to Maskat, and then followed the treaty about Kung. They gave passports to native ships under very stringent conditions and limitations. M. de Thevenot $\uparrow$ visited Kung in 1665. He left Basra in the ship of an Armenian of 260 tons, 18 guns, and 31 seamen-the captain, gunner, and two sailors being the only "Franks." She was furnished with three passports, Portuguese, English, and Dutch. "The captain was a good sailor, but knew not how to set off a course, nor take an observation, nor read or write." The quarrels of the ignorant skipper with the Arab pilot are given at length, and "indeed, it was commonly the Shiraz wine or Congo brandy that raised all this huff and din." He says, "Congo has a little castle defended by three pieces of cannon." Sulphur was exported. Water had to be brought from a distance. "The custom-house receives a great deal of money, especially within these last two years, on account of the extortions of the governor of Bender Abbassi. One-half the profits belongs to the King of Portugal, who, after the loss of Ormus, still so infested the King of Persia by his ships, that continually kept cruising along that coast, that Persia was constrained to make peace with him upon conditions. The King of Portugal keeps an agent there, who flies the Portuguese flag. The Dutch used to send a factor to buy pearls there from Bahrein." He stayed sixteen days at Kung.

His description of dealing with water-spouts seems worth quoting. "Besides the devotions of the Holy Gospel, the human remedies which seamen use against water-spouts is to furl all the sails, and to fire some guns with shot against the pipe of the spout. If that succeed not"-he describes a curious superstition of "cutting it with a black-handled knife, without which they never go on board for that reason." This latter is probably from hearsay.

I have not been able to trace an account of the date of the abandonment of Kung, or of the reasons for it. Captain Hamilton, $\ddagger 1688-1723$, says the Portuguese lately had a factory at Kong.

\section{THE GERMAN DEEP-SEA EXPEDITION.§}

Further news of the voyage of scientific investigation in the Valdivia has reached us in a letter from Prof. Chun, the leader of the expedition, to Sir John Murray, dated January 20, 1899. The voyage down the Atlantic to the edge of the antarctic ice, and thence through the Indian ocean, has been most successful, the soundings alone serving to fill an important gap on the charts, and showing that the average depth of the Southern ocean must be considerably greater than has been supposed. Sir John Murray considers that the success of the German investiga:ors

\footnotetext{
* 'Voyages du Ch. Chardin en Perse,' etc. 2 vols. 4to. 1735.

+ 'The Travels of M. de 'Thevenot,' etc. London, 1687. Newly done out of French.

$\ddagger$ New Account of the East Indies, etc., 1727.

$\S$ Chart, p. 336.
} 